Original Research Articles

\title{
Therapeutic Effect of Red Spinach (Amaranthus tricolor L.) Extract on Pancreatic MDA Levels Rats (Rattus norvegicus) Exposed to MLD-STZ
}

\author{
Kartika Rahma $^{1 *}$, Ois Nurcahyanti \\ ${ }^{1}$ Pharmacy Department, Faculty of Health Science and Technology, Binawan University, Indonesia \\ ${ }^{2}$ Environmental Engineering Department, Faculty of Health Science and Technology, Binawan University,
} Indonesia

Article Info

History

Received: 03 Nov 2021

Accepted: 23 Dec 2021

Available: 31 Dec 2021

\begin{abstract}
Background: Several studies have reported that diabetes mellitus (DM) in patient can cause complications to death that occur due to oxidative stress conditions. Red spinach extract was found to be rich in antioxidant compounds. However, there has been no further research on the ability of red spinach to lower blood glucose levels and prevent oxidative stress, which can be seen from the levels of malondialdehyde (MDA; a marker of oxidative stress) in the DM body.

Objective: This study aims to determine whether there is a change in blood glucose levels and MDA levels in DM animal models between the groups that were given red spinach extract and not.

Methods: This study used white rats (Rattus norvegicus) which were divided into 5 groups: $\mathrm{C}(-)$ group in which the rats were not induced by diabetogenic agent and were not treated; $\mathrm{C}(+)$ group, the rats were made DM induced by multiple low dose streptozotocin (MLD-STZ); and T1, T2, and T3 groups were exposed to MLD-STZ and treated with red spinach extract (Amaranthus tricolor L.) at a dose of 200 $\mathrm{mg} / \mathrm{kgBW}, 300 \mathrm{mg} / \mathrm{kgBW}$ and $400 \mathrm{mg} / \mathrm{kgBW}$, respectively. Blood sugar levels were checked by using glucometer digital. Meanwhile, MDA levels were measured by thiobarbituric acid (TBA) test using protein isolates from the pancreas of each rat.

Results: The results showed that the average MDA levels in the C-, C+, T1, T2, and $\mathrm{T} 3$ groups were $1.759 \pm 0.08,2.280 \pm 0.15,2.303 \pm 0.11,1.927 \pm 0.06$, and $1.801 \pm 0.04$. While the average blood sugar levels in the $\mathrm{C}-, \mathrm{C}+, \mathrm{T} 1, \mathrm{~T} 2$, and $\mathrm{T} 3$ groups were 114.4 $\pm 8.82,464 \pm 72.78,421.2 \pm 37.60,140.6 \pm 20.19$, and $176 \pm 13.06$.

Conclusion: It can be concluded that the administration of red spinach extract therapy in DM model rats was able to reduce both glucose levels and MDA levels. It is also believed to be able to prevent oxidative stress in cells which causes tissue damage.
\end{abstract}

Keywords: Diabetes mellitus; red spinach; MDA level; blood glucose Permalink/ DOI: https://doi.org/10.14710/jbtr.v7i3.12536

\section{INTRODUCTION}

Diabetes mellitus (DM) is one of the four priority noncommunicable diseases that are targets for follow-up by world leaders. This disease, which is characterized by soaring glucose levels in the blood, or what is commonly known as hyperglycemia, has an ever-increasing number of cases over the last few decades. Not only does it increase the risk of complications, it also increases the risk of death.

\footnotetext{
* Corresponding author:

E-mail: kartika.rahma@binawan.ac.id

(Kartika Rahma)
}

The prevalence of diabetes increased sharply in lowincome countries, including Indonesia, compared to high-income countries ${ }^{1}$. In Indonesia, diabetes mellitus is one of the main causes of death in Indonesia with the percentage of deaths increasing from year to year ${ }^{2}$. This fact is also supported by data recorded at the International Diabetes Federation (IDF) in 2017, Indonesia is in the sixth position in the world with the highest prevalence of DM with 10.3 million DM sufferers. In 2045, the International Diabetes Federation predicts that there will be 16.7 million people with diabetes in Indonesia ${ }^{3}$. 
Chronic hyperglycemia is associated with complications of diabetes. Several signaling pathways can be altered by experiencing hyperglycemia in different tissues, resulting in oxidative stress. Signaling pathways that are directly triggered by hyperglycemia play an important role in diabetic complications due to the production of Reactive Oxygen Species (ROS). The accumulation of ROS causes oxidative stress, up to cell death $^{4}$. In addition to excessive ROS production, there was also an increase in malondialdehyde (MDA) levels which are the main product of lipid peroxidation by ROS. MDA is also referred to as a marker of oxidative stress. The presence of MDA has been widely reported in diabetic patients ${ }^{5}$.

DM is a lifelong disease, but it can be controlled with a healthy lifestyle such as medical therapy and physical activity simultaneously with pharmacological interventions. Two pharmacological interventions for diabetes, namely with oral antihyperglycemic or oral antidiabetic drugs and/or a mixture. Modern antidiabetic drugs such as metformin, glibenclamide, and sulfonylureas are often complained of because they have some side effects. Side effects that appear such as diarrhea, vomiting, stomach, weight loss, can cause hypoglycemia. ${ }^{6-8}$ Ttreatment with herbal plants that are believed to have a smaller risk of side effects than modern medicines.

Several previous studies have shown that the increase in blood sugar is emphasized by therapy using herbal plants, one of which is the administration of red spinach extract (Amaranthus tricolor L. $)^{9}$. Red spinach is considered superior to other types of spinach because it contains high antioxidants ${ }^{10}$. This antioxidant content is able to capture free radicals / ROS that exist in DM conditions. However, the relationship between red spinach extract therapy and its ability to reduce MDA levels in DM conditions is still not widely known. In this study, the effect of red spinach (Amaranthus tricolor L.) extract on the level of oxidative stress in the animal's body will be identified quantitatively through pancreatic MDA protein levels and blood sugar monitoring.

\section{MATERIALS AND METHODS}

\section{Preparation of Experimental Animals}

This study used healthy male white rats (Rattus norvegicus) Wistar strain with a body weight of \pm 150 250 grams aged 2-3 months, as many as 25 mice were adapted for 2 weeks in the Lab. Pharmacology, Binawan University. All rats were divided into 5 groups, including: (1) healthy group/C(-), not given any preoperative treatment; (2) group of rats with DM type 1 / C(+), group of rats induced by MLD-STZ alone without any therapy; and the other groups (3), (4), \& (5) were the therapeutic rat group (T1, T2, and T3). Groups T1, T2, and T3 were groups of rats receiving therapy with red spinach extract (Amaranthus tricolor L.) at a dose of 200 $\mathrm{mg} / \mathrm{kgBW}, 300 \mathrm{mg} / \mathrm{kgBW}, 400 \mathrm{mg} / \mathrm{kgBW}$, respectively, after the rats were declared DM due to MLD-STZ induction.

\section{Preparation of Red Spinach Leaf Extract}

About $5 \mathrm{~kg}$ of fresh red spinach (Amaranthus tricolor L.) were washed and air-dried to obtain dry red spinach leaves. Then the dried red spinach leaves are blended / ground to obtain red spinach powder. Dried red spinach powder was macerated with $70 \%$ ethanol solvent with 1:6 ratio, then the macerate was concentrated using a vacuum rotary evaporator and filtered to obtain a thick extract. The ethanol extract of red spinach leaves was made at a dose of $200 \mathrm{mg} / \mathrm{kgBW}, 300 \mathrm{mg} / \mathrm{kgBW}, 400 \mathrm{mg} / \mathrm{kgBW}$.

Thick extract was screened for phytochemicals to determine the active compounds in it. Phytochemical screening was carried out by adopting several methods that have been common and have been widely used in previous studies. The identification of alkaloid compounds was carried out using the Dragendorf test and Wagner's test. Saponin compounds were tested using the foam method. The presence of tannins and phenols in the extract was tested using gelatin and salt. The flavonoid compounds in the extract were tested using Shinoda's test/ Mg-hydrochloride reduction test. The identification of triterpenoid and steroid compounds was carried out by Salkowski's test and Libermann-Burchard's test. Meanwhile, to identify the presence of glycosides, the Keller-Killani test was carried out ${ }^{11}$.

\section{Measurement of Blood Glucose Level}

Measurement of blood glucose levels of experimental animals was carried out 3 times during the study, namely: 1) Before injection of MLD-STZ, as the initial blood glucose level, 2) After induction of MLD-STZ (blood glucose levels exceeding $135 \mathrm{mg} / \mathrm{dL}$ rats were declared DM), and 3) after therapy with red spinach extract. Measurement of blood sugar levels using a glucometer stick and a digital glucometer (FamilyDr. Blood Glucose AGM-513S) according to the instructions for use.

\section{Preparation of MLD-STZ Solution}

Streptozotocin (STZ) 100 grams was dissolved with $1.5 \mathrm{~mL}$ of citrate buffer $\mathrm{pH} 4.5$ and homogenized with a vortex. STZ solution was stored at $4{ }^{\circ} \mathrm{C}$ as stock to be injected into experimental animals with dosage conditions adjusted to the body weight of the experimental animals. The STZ dose used was $20 \mathrm{mg} / \mathrm{kg}$ BW, 5 times, which was given once a day for 5 consecutive days (multiple low dose) by intraperitoneal $^{12}$.

\section{MDA for the Measurement}

0.2 gram of the organ was cut into small pieces and then crushed in a cold mortar placed on an ice block and added $1 \mathrm{ml}$ of $0.9 \% \mathrm{NaCl}$. The homogenate was then transferred to a small test tube and centrifuged at 8000 rpm for 20 minutes and the supernatant was taken. The supernatant was taken $100 \mathrm{~L}$, added with $550 \mathrm{~L}$ distilled water, $100 \mathrm{~L} \mathrm{TCA}, 250 \mathrm{~L} 1 \mathrm{~N} \mathrm{HCl}$, and $100 \mathrm{~L} \mathrm{Na-Thio.}$ For each addition of reagent, the mixed solution was homogenized with a vortex, then centrifuged at $500 \mathrm{rpm}$. for 15 minutes. The supernatant was separated and transferred to a new test tube. The solution was incubated in a water bath at $100{ }^{\circ} \mathrm{C}$. The absorbance of the sample was measured maximally for the TBA test and plotted on a standard curve that had been made to calculate the concentration of the sample ${ }^{13}$.

\section{Data Analysis}

The research data were analyzed using the ShapiroWilk normality test and the Levene homogeneity test. 
Then, it was continued with the One-way Anova comparative test and the post hoc test-Tukey.

\section{RESULTS}

Phytochemical screening is the initial stage to identify chemical compounds contained in an extract. Based on the results of phytochemical tests from red spinach extract (Amaranthus tricolor L.), it was found that several secondary compounds contained in red spinach extract were alkaloids, flavonoids, saponins, tannins, steroids, phenolics, and glycosides. As summarized in Table 1., red spinach extract showed a positive reaction with the 7 secondary compounds above, and did not show any reaction to the triterpenoids in the extract.

Table 1. Phytochemical Test Results of Red Spinach Leaf Extract

\begin{tabular}{ccc}
\hline No. & Secondary Compounds & Results \\
\hline 1 & & + \\
2 & Alkaloids & + \\
3 & Saponins & + \\
4 & Tannins & + \\
5 & Phenolic & + \\
6 & Flavonoids & - \\
7 & Triterpenoids & + \\
8 & Steroid & + \\
\hline
\end{tabular}

$(+)$ : contained in the extract

Measurement of blood glucose levels was carried out at three different times with 3 repetitions per rat. The first measurement is on all rats in each group. The mean blood sugar obtained in the $\mathrm{C}-, \mathrm{C}+, \mathrm{T} 1, \mathrm{~T} 2$, and $\mathrm{T} 3$ groups, respectively, were $120.2 \pm 11.26 \mathrm{mg} / \mathrm{dL}, 130.0$ $\pm 4.80 \mathrm{mg} / \mathrm{dL}, 111.6 \pm 7.70 \mathrm{mg} / \mathrm{dL}, 118.0 \pm 16.48$ $\mathrm{mg} / \mathrm{dL}$, and $114.2 \pm 11.39 \mathrm{mg} / \mathrm{dL}$, as shown in Table 2 . The second measurement of glucose levels was carried out on the day after stz induction, so that measurements were carried out only in the group induced by STZ which was $\mathrm{C}+, \mathrm{T} 1, \mathrm{~T} 2$, and $\mathrm{T} 3$. The average blood sugar obtained in groups $\mathrm{C}+, \mathrm{T} 1, \mathrm{~T} 2$, and $\mathrm{T} 3$ respectively were $402.4 \pm 72.57 \mathrm{mg} / \mathrm{dL}, 410.8 \pm 30.99 \mathrm{mg} / \mathrm{dL}, 407.0 \pm$ $46.32 \mathrm{mg} / \mathrm{dL}$, and $404.8 \pm 42.55 \mathrm{mg} / \mathrm{dL}$. The third blood sugar measurement was on the 7 th day of therapy with red spinach extract. To see the latest blood sugar comparison, the blood sugar measurement at the third time was carried out in all groups including the $\mathrm{C}$ - group. The average blood sugar data obtained were $114.4 \pm 8.82$ $\mathrm{mg} / \mathrm{dL}, 429.6 \pm 65.99 \mathrm{mg} / \mathrm{dL}, 421.2 \pm 37.60 \mathrm{mg} / \mathrm{dL}$, $140.6 \pm 20.19 \mathrm{mg} / \mathrm{dL}$, and $176.0 \pm 13.06 \mathrm{mg} / \mathrm{dL}$ which data were from groups $\mathrm{C}-, \mathrm{C}+, \mathrm{T} 1, \mathrm{~T} 2$, and $\mathrm{T} 3$ respectively.

Determination of MDA levels was carried out using the Thiobarbituric acid test method. The sample used for the determination of MDA levels was protein isolate from the pancreas of each rat in all groups. All rats were dissected and protein isolated from their pancreas organs on day 8 after the therapy group was finished given red spinach extract for 7 consecutive days. Based on the results of the study, the average concentration of MDA obtained by the Thiobarbituric acid test method in the pancreas of rats in groups $\mathrm{C}-, \mathrm{C}+, \mathrm{T} 1, \mathrm{~T} 2$ and $\mathrm{T} 3$ respectively was $1.759 \pm 0.08 \mu \mathrm{g} / \mathrm{mL}, 2.280 \pm 0.15$ $\mu \mathrm{g} / \mathrm{mL}, 2.303 \pm 0.11 \mu \mathrm{g} / \mathrm{mL}, 1.927 \pm 0.06 \mu \mathrm{g} / \mathrm{mL}$ dan $1.801 \pm 0.04 \mu \mathrm{g} / \mathrm{mL}$ (Table 3).

Table 2. Comparison of Blood Glucose Levels of All Groups

\begin{tabular}{cccc}
\hline & \multicolumn{3}{c}{ Blood Glucose level (mg/dL) } \\
\cline { 2 - 4 } Groups & $\begin{array}{c}\text { Before MLD- } \\
\text { STZ } \\
\text { induction }\end{array}$ & $\begin{array}{c}\text { After 5 days } \\
\text { of MLD-STZ } \\
\text { induction }\end{array}$ & $\begin{array}{c}\text { After 7 Days of } \\
\text { Therapy }\end{array}$ \\
\hline C- & $120.2 \pm 11.26$ & - & $114.4 \pm 8.82 * *$ \\
C+ & $130.0 \pm 4.80$ & $402.4 \pm 72.57$ & $429.6 \pm 65.99 *$ \\
T1 & $111.6 \pm 7.70$ & $410.8 \pm 30.99$ & $421.2 \pm 37.60 *$ \\
T2 & $118.0 \pm 16.48$ & $407.0 \pm 46.32$ & $140.6 \pm 20.19$ \\
& $114.2 \pm 11.39$ & $404.8 \pm 42.55$ & $176.0 \pm$ \\
T3 & $11.06 * *$ \\
\hline * Sig. $\mathrm{p}<0.05$ compared to C- & \\
** Sig. $\mathrm{p}<0.05$ compared to C+
\end{tabular}

Table 3. Comparison of MDA Levels of All Groups

\begin{tabular}{cccc}
\hline \multirow{2}{*}{ Groups } & \multicolumn{2}{c}{$\begin{array}{c}\text { MDA Concentration } \\
(\mu \mathrm{g} / \mathbf{m L})\end{array}$} & Post Hoc Test Result \\
\cline { 2 - 3 } & Average & stdev & $* *$ \\
C- & 1.759 & 0.08 & $*$ \\
$\mathrm{C}+$ & 2.280 & 0.15 & $*$ \\
$\mathrm{~T} 1$ & 2.303 & 0.11 & $* *$ \\
$\mathrm{~T} 2$ & 1.927 & 0.06 & $* *$ \\
$\mathrm{~T} 3$ & 1.801 & 0.04 &
\end{tabular}

* Sig. $\mathrm{p}<0.05$ compared to $\mathrm{C}$ -

** Sig. $\mathrm{p}<0.05$ compared to $\mathrm{C}+$

\section{DISCUSSION}

In previous studies, it was known that red spinach extract contains several secondary metabolite compounds including antioxidants ${ }^{10}$. This is in line with the results of the phytochemical test of the ethanolic extract of red spinach which reacted positively to several secondary compounds, one of which was flavonoid compounds.

Flavonoid compounds were identified using concentrated $\mathrm{Mg}$ and $\mathrm{HCl}$. The formation of a red color after the addition of concentrated $\mathrm{Mg}$ and $\mathrm{HCl}$ in the extract of red spinach (Amaranthus tricolor L.), this indicates that the sample contains flavonoids (Table 1.). Flavonoid compounds will be reduced with $\mathrm{Mg}$ and $\mathrm{HCl}$ to produce a red or yellow color ${ }^{14}$.

The results of this study showed that the average blood glucose of $\mathrm{C}(+)$ group induced by MLD-STZ and not treated had a significant increase in blood sugar at 429.6 $\mathrm{mg} / \mathrm{dL}$ compared to blood glucose levels in C(-) group, namely $114.4 \mathrm{mg} / \mathrm{dL}$. This is in accordance with previous studies that normal blood glucose in mice ranges from (111.72 155.60) $\mathrm{mg} / \mathrm{dL}$, while in diabetes mellitus, blood glucose levels are above normal, and generally it is said to be diabetes if blood glucose $>201 \mathrm{mg}$. $/ \mathrm{dL}^{15}$. So, it can be concluded that $\mathrm{C}(+)$ group is already in $\mathrm{DM}$ condition. 
STZ has high cell specificity compared to other diabetogenic agents. This compound belongs to the group that is soluble in air and if it reacts in the body it will be toxic to cells, thus affecting blood glucose ${ }^{16}$. The action of STZ on the islets of Langerhans is accompanied by changes in insulin and glucose in the blood. This is because STZ can interfere with glucose oxidation and decrease insulin biosynthesis and secretion. The intracellular action of STZ causes DNA changes in pancreatic cells and acts as a nitrogen oxide (NO) radical donor and produces Reactive Oxygen Species (ROS) which will increase the number of free radicals in the pancreas. Excessive NO radicals will react with superoxide radicals to form peroxynitrite which is toxic to pancreatic cells ${ }^{16}$. This situation is very capable of damaging beta cells and inhibiting insulin secretion which results in an increase in the amount of blood glucose. Blood sugar levels that exceed normal are an indication of diabetes ${ }^{17}$. A similar study stated that giving STZ, in low doses (MLD-STZ, Multiple Low Dose Streptozotocin), in experimental animals given i.p (intraperitoneal) injection at a dose of $<40 \mathrm{mg} / \mathrm{kg} \mathrm{BW}$ for 5 consecutive days caused hyperglycemia / $\mathrm{DM}^{18}$.

Meanwhile, in the therapy group, which was a group of mice induced by MLD-STZ, and treated with extracts at a dose of $200 \mathrm{mg} / \mathrm{kg} \mathrm{BW}, 300 \mathrm{mg} / \mathrm{kgBW}$ and 400 $\mathrm{mg} / \mathrm{kgBW}$, respectively, for groups $\mathrm{T} 1, \mathrm{~T} 2, \mathrm{~T} 3$, there were groups who experienced a decrease in glucose levels, and there was also a group whose blood glucose levels did not decrease.

Based on statistical data from Post Hoc Test-Tukey (Table 2.) it is known that the average blood sugar of the T2 and T3 groups decreased significantly $(\mathrm{p}<0.05)$ compared to the $\mathrm{C}(+)$ group, while the average blood sugar of the T1 group was not different. significantly compared to the $\mathrm{C}(+)$ group. These results indicate that therapy given using red spinach extract at a dose of 200 $\mathrm{mg} / \mathrm{kgBW}$ had no effect in lowering blood sugar in DM rats, while therapy in DM rats using red spinach extract at a dose of $300 \mathrm{mg} / \mathrm{kgBW}$ and $400 \mathrm{mg} / \mathrm{kgBW}$ could reduce blood sugar levels to normal

The same trend was also seen in the MDA levels of the pancreas of rats (Table 3). There was a significant $(\mathrm{p}<0.05)$ decrease in MDA levels in DM rats when treated with red spinach extract at doses of 300 $\mathrm{mg} / \mathrm{kgBW}$ and $400 \mathrm{mg} / \mathrm{kgBW}$ which were in groups T1 and T2 compared to MDA levels in $\mathrm{C}(+)$ group. Meanwhile, in DM rats that were only treated with red spinach extract at a dose of $200 \mathrm{mg} / \mathrm{kgBW}$, the mean pancreatic MDA levels in the groups were not significantly different $(\mathrm{p}<0.05)$ compared to $\mathrm{C}(+)$ group.

Hyperglycemia conditions that change several signaling pathways, causing complications of diabetes ${ }^{4}$. In this condition, there is an increase in the number of ROS, AGEs, MGO which causes oxidative stress. The increase in MDA levels in the $\mathrm{C}(+)$ group of rats occurred due to an increase in the amount of excess ROS in DM conditions that trigger oxidative stress to complications. The main target of ROS is lipid. One of the most widely produced decomposition products of lipid oxidation is malondialdehyde (MDA). These compounds are formed through the biosynthesis of prostaglandins, such as endoperoxidase of polyunsaturated fatty acids (PUFA). Changes in MDA levels indicate a change in ROS activity. Increased ROS production affects the increase in MDA levels.

In this study, the increase in MDA that occurred in the T2 and T3 groups was able to be suppressed by antioxidant therapy from red spinach (Amaranthus tricolor L.) extract at a dose of $300 \mathrm{mg} / \mathrm{kgBW}$ and 400 $\mathrm{mg} / \mathrm{kgBW}$. However, administration of $200 \mathrm{mg} / \mathrm{kgBW}$ red spinach (Amaranthus tricolor L.) extract therapy was not sufficient to suppress MDA formation in the T1 group, thus failing to reduce MDA and blood sugar levels in that group.

The flavonoid compounds contained in red spinach extract act as free radical scavengers with proton donors. Singlet electrons from ROS received by flavonoids through proton donors on the hydroxyl group of flavonoids will form flavonoid radicals ${ }^{19,20}$. However, the unpaired electron is delocalized by the resonance of the benzene structure of the flavonoid compound and maintains the stability of the compound ${ }^{21}$. So that radical flavonoid compounds have lower radical activity or even are not reactive. The decrease in the number of ROS was followed by a decrease in the activity of MDA production and the activation of blood sugar controlling proteins so that glucose levels in the blood could be controlled properly.

\section{CONCLUSION}

Based on this study, it is known that therapy with red spinach extract at a dose of $200 \mathrm{mg} / \mathrm{kgBW}$ has not been able to reduce blood sugar levels and pancreatic MDA in rats. Meanwhile, therapy using red spinach (Amaranthus tricolor L.) extract at a dose of $300 \mathrm{mg} / \mathrm{kgBW} 400$ $\mathrm{mg} / \mathrm{kgBW}$ in DM rats was able to significantly reduce blood glucose and pancreatic MDA of rats. Using these two doses is believed to also be able to inhibit the oxidative stress pathway in DM animal model.

\section{ACKNOWLEDGMENTS}

This research was supported by Kementrian Riset dan Teknologi / Badan Riset dan Inovasi Nasional (RISTEKBRIN) 2021 grant number 064/E4.1/AK.04.PT/2021; 3538/LL3/KR/2021; 019/LT/UBN.LPPM/VII/2021.

\section{REFERENCES}

1. WHO Global Report, 2016. Global Reports on Diabetes, WHO Press: France.

https://www.who.int/diabetes/global-report/en/.

2. Laporan Hasil Riset Kesehatan Dasar (Riskesdas), 2018. https://www.litbang.kemkes.go.id/laporanriset-kesehatan-dasar-riskesdas/.

3. International Diabetes Federation. IDF Diabetes Atlas Eighth Edition. 2017, ISBN: 978-2-930229-874.

4. Volpe CM, Villar-Delfino PH, Dos Anjos PM, Nogueira-Machado JA. Cellular death, reactive oxygen species (ROS) and diabetic complications. Cell death \& disease. 2018 Jan 25;9(2):1-9. DOI: $10.1038 / \mathrm{s} 41419-017-0135-\mathrm{z}$

5. Tiwari BK, Pandey KB, Abidi AB, Rizvi SI. Markers of oxidative stress during diabetes mellitus. Journal of biomarkers. 2013; 378790:1-8, http://dx.doi.org/10.1155/2013/378790 
6. Zhai S, Georgy A, Liang Z, Zhi J. Pharmacokinetic and pharmacodynamic drug interaction study of piragliatin, a glucokinase activator, and glyburide, a sulfonylurea, in type 2 diabetic patients. Clinical pharmacology in drug development. 2016 Nov;5(6):552-6. DOI: 10.1002/cpdd.276

7. Lamos EM, Stein SA, Davis SN. Combination of glibenclamide-metformin $\mathrm{HCl}$ for the treatment of type 2 diabetes mellitus. Expert opinion on pharmacotherapy. 2012 Dec 1;13(17):2545-54. DOI: $10.1517 / 14656566.2012 .738196$

8. Abdulkadir AA, Thanoon IA. Comparative effects of glibenclamide and metformin on C-reactive protein and oxidant/antioxidant status in patients with type II diabetes mellitus. Sultan Qaboos University Medical Journal. 2012 Feb;12(1):55. DOI: $10.12816 / 0003088$

9. Putri CA, Pradana DA, Susanto Q. Efek Ekstrak Etanolik Daun Bayam Merah (Amaranthus tricolor L.) Terstandar terhadap Indeks Massa tubuh dan Kadar Glukosa Darah Pada Tikus Sprague Dawley yang Diberikan Diet Tinggi Lemak sebagai Upaya Preventif Obesitas. PHARMACY: Jurnal Farmasi Indonesia (Pharmaceutical Journal of Indonesia). 2017 Jan 21;13(02):150-61.

DOI: $10.30595 /$ pji.v13i02.1251

10. Kusmiati, R., Pertiwi A.A., 2014, Pengujian Ekstrak Aseton Daun Bayam (Amaranthus Sp) Sebagai Senyawa Antiradikal Dpph, Antibakteri Dan Identifikasi Senyawa Aktif Dengan KG SM, Proceeding Biology Education Conference. Vol 11(1). Surakarta, Indonesia; Seminar Nasional XI Pendidikan Biologi FKIP UNS.

11. Shaikh JR, Patil MK. Qualitative tests for preliminary phytochemical screening: An overview. International Journal of Chemical Studies. 2020;8(2):603-8.

DOI: $10.22271 /$ chemi.2020.v8.i2i.8834

12. Furman BL. Streptozotocin-Induced Diabetic Models in Mice and Rats. Current Protocols. 2021 Apr;1(4):e78. DOI: doi.org/10.1002/cpz1.78

13. Schmedes A, Hølmer G. A new thiobarbituric acid (TBA) method for determining free malondialdehyde (MDA) and hydroperoxides selectively as a measure of lipid peroxidation. Journal of the American Oil Chemists' Society. 1989 Jun;66(6):813-7. https://doi.org/10.1007/BF02653674
14. Nafisah,M., Tukiran., Suyanto., Nurul, H. 2014, Uji Skrining Fitokimia Pada Ekstrak Heksan, Kloroform, Dan Metanol Dari Tanaman Patikan Kebo (Euphorbia hirta), Prosiding Seminar Nasional Kimia, 279- 286, 20; Seminar Nasional Kimia.

15. Hardiyanti S, Harmayetty H, Widyawati IY. Kadar Glukosa Darah Mencit (Mus Musculus) Diabetes Mellitus Paska Pemberian Model Latihan Isometrik. Critical Medical and Surgical Nursing Journal. 2012;1(1):46-52. http://dx.doi.org/10.20473/cmsnj.v1i1.11971

16. Szkudelski T. Streptozotocin-nicotinamide-induced diabetes in the rat. Characteristics of the experimental model. Experimental biology and medicine. 2012 May;237(5):481-90. DOI: $10.1258 /$ ebm.2012.011372

17. American Diabetes Association. Classification and Diagnos of Diabetes. Diabetes Care 2016;39(Suppl. 1):S13-S22 | DOI: 10.2337/dc16-S005

18. Veerapur VP, Prabhakar KR, Thippeswamy BS, Bansal P, Srinivasan KK, Unnikrishnan MK. Antidiabetic effect of Ficus racemosa Linn. stem bark in high-fat diet and low-dose streptozotocin-induced type 2 diabetic rats: a mechanistic study. Food Chemistry. 2012 May 1;132(1):186-93. https://doi.org/10.1016/j.foodchem.2011.10.052

19. Treml J, Šmejkal K. Flavonoids as potent scavengers of hydroxyl radicals. Comprehensive reviews in food science and food safety. 2016 Jul;15(4):720-38. https://doi.org/10.1111/1541-4337.12204

20. Nimse SB, Pal D. Free radicals, natural antioxidants, and their reaction mechanisms. RSC advances. 2015;5(35):27986-8006.

DOI: $10.1039 / C 4 R A 13315 C$

21. Vásquez-Espinal A, Yañez O, Osorio E, Areche C, García-Beltrán O, Ruiz LM, Cassels BK, Tiznado W. Theoretical study of the antioxidant activity of quercetin oxidation products. Frontiers in chemistry. 2019 Nov 27;7:818. https://doi.org/10.3389/fchem.2019.00818 